\title{
Cancer-associated fibroblasts and their role in tumor progression
}

\author{
M.S. Ermakov ${ }^{1}$, A.A. Nushtaeva ${ }^{1}$, V.A. Richter ${ }^{1}$, O.A. Koval ${ }^{1,2} \otimes$ \\ ${ }^{1}$ Institute of Chemical Biology and Fundamental Medicine of the Siberian Branch of the Russian Academy of Sciences, Novosibirsk, Russia \\ ${ }^{2}$ Novosibirsk State University, Novosibirsk, Russia \\ ه o_koval@ngs.ru
}

Abstract. The stromal elements of a malignant tumor can promote cancer progression and metastasis. The structure of the tumor stroma includes connective tissue elements, blood vessels, nerves, and extracellular matrix (ECM). Some of the cellular elements of the tumor stroma are cancer-associated fibroblasts (CAFs). The origin and function of CAFs have been actively studied over the past thirty years. CAFs produce collagen, the main scaffold protein of the extracellular matrix. Collagen in the tumor stroma stimulates fibrosis, enhances the rigidity of tumor tissue, and disrupts the transmission of proliferation and differentiation signaling pathways. CAFs control tumor angiogenesis, cell motility, tumor immunogenic properties, and the development of resistance to chemo- and immunotherapy. As a result of metabolic adaptation of rapidly growing tumor tissue to the nutrients and oxygen deprivation, the main type of energy production in cells changes from oxidative phosphorylation to anaerobic glycolysis. These changes lead to sequential molecular alterations, including the induction of specified transcriptional factors that result in the CAFs activation. The molecular phenotype of activated CAFs is similar to fibroblasts activated during inflammation. In activated CAFs, alpha-smooth muscle actin ( $\alpha$-SMA) is synthetized de novo and various proteases and fibronectin are produced. Since CAFs are found in all types of carcinomas, these cells are potential targets for the development of new approaches for anticancer therapy. Some CAFs originate from resident fibroblasts of the organs invaded by the tumor, while others originate from epithelial tumor cells, which are undergoing an epithelial-mesenchymal transition (EMT). To date, many molecular and metabolic inducers of the EMT have been discovered including the transforming growth factor-beta (TGF- $\beta$ ), hypoxia, and inflammation. This review classifies modern concepts of molecular markers of CAFs, their functional features, and discusses the stages of epithelial-mesenchymal transition, and the potential of CAFs as a target for antitumor therapy.

Key words: cancer-associated fibroblasts; epithelial-to-mesenchymal transition; carcinoma; hypoxia.

For citation: Ermakov M.S., Nushtaeva A.A., Richter V.A., Koval O.A. Cancer-associated fibroblasts and their role in tumor progression. Vavilovskii Zhurnal Genetiki i Selektsii = Vavilov Journal of Genetics and Breeding. 2022;26(1):14-21. DOI 10.18699/VJGB-22-03

\section{Опухоль-ассоциированные фибробласты и их роль в опухолевой прогрессии}

\author{
М.С. Ермаков ${ }^{1}$, А.А. Нуштаева ${ }^{1}$, В.А. Рихтер ${ }^{1}$, О.А. Ковамь ${ }^{1,2} \otimes$ \\ ${ }^{1}$ Институт химической биологии и фундаментальной медицины Сибирского отделения Российской академии наук, Новосибирск, Россия \\ 2 Новосибирский национальный исследовательский государственный университет, Новосибирск, Россия \\ 凶o_koval@ngs.ru
}

Аннотация. Стромальные элементы опухоли могут стимулировать прогрессию опухолевого роста и метастазирование. В структуру опухолевой стромы входят соединительнотканные элементы, сосуды, нервы и внеклеточный матрикс. Одним из клеточных элементов стромы опухоли являются опухоль-ассоциированные фибробласты (ОАФ), происхождение и функции которых активно изучают на протяжении последних тридцати лет. ОАФ продуцируют основной каркасный белок внеклеточного матрикса - коллаген, избыток которого в строме опухоли стимулирует фиброз, повышает жесткость опухолевой ткани и нарушает передачу сигналов пролиферации и дифференцировки. ОАФ контролируют ангиогенез в опухоли, подвижность опухолевых клеток, иммуногенные свойства опухоли и развитие резистентности к химиопрепаратам и иммунотерапии. В результате метаболической адаптации быстрорастущей опухолевой ткани к нехватке питательных веществ и кислорода, при конверсии основного типа производства энергии в клетках с окислительного фосфорилирования на анаэробный гликолиз инициируются молекулярные изменения, в том числе индукция определенных транскрипционных факторов, которые обусловливают активацию ОАФ. Молекулярный фенотип активированных ОАФ имеет сходство с фибробластами, активированными в процессе воспаления. В активированных ОАФ происходит de novo синтез альфа-актина гладкой мускулатуры ( $\alpha$-SMA), продукция 


\begin{abstract}
различных протеаз и фибронектина. Поскольку ОАФ обнаружены во всех типах карцином, эти клетки могут быть мишенями для разработки новых подходов противоопухолевой терапии. Часть ОАФ происходит из резидентных фибробластов пораженного опухолью органа, другие берут свое начало из опухолевых эпителиоцитов, претерпевая эпителиально-мезенхимальный переход. На сегодняшний день обнаружено большое количество молекулярных и метаболических индукторов эпителиально-мезенхимального перехода, к которым относят трансформирующий фактор роста бета (TGF- $\beta$ ), гипоксию и воспаление. В данном обзоре систематизированы современные представления о молекулярных маркерах ОАФ, их функциональных особенностях, этапах эпителиально-мезенхимального перехода и обсуждается возможность использования ОАФ в качестве мишеней для противоопухолевой терапии.

Ключевые слова: опухоль-ассоциированые фибробласты; эпителиально-мезенхимальный переход; карцинома; гипоксия.
\end{abstract}

\section{The biology of cancer-associated fibroblasts}

Modern concept of tumor morphology postulates that solid tumors are formed by epithelial and stromal cells, such as fibroblasts, endothelial cells, and immune cells (Wang et al., 2017). Stromal cells with a fibroblast-like phenotype, the so-called cancer-associated fibroblasts (CAFs), in contrast to normal fibroblasts, contain various chromosomal abnormalities, such as duplications, multiple rearrangements, and even the loss of entire chromosomes (Hosein et al., 2010). CAFs control tumor angiogenesis, motility and metastasis of cancer cells, tumor immunogenic properties, and the development of resistance to chemotherapy and immunotherapy (Tripathi et al., 2012; Alkasalias et al., 2018; Nushtaeva et al., 2018).

A meta-analysis of the clinical relevance of the tumor stroma has demonstrated the association of high CAFs content with the advanced stages of tumor progression, as well as with the high risk of local recurrence after tumor resection (Knops et al., 2020).

\section{Heterogeneity of CAFs' percussors cells}

In 1995, a heterogeneous origin of CAFs was hypothesized by Rønnov-Jessen and colleagues, who showed that breast cancer CAFs can originate from resident fibroblasts, vascular smooth muscle cells, and pericytes (Rønnov-Jessen et al., 1995). To date, it has been shown that precursors of mesenchymal cells from the red bone marrow, endothelial and epithelial cells, resident fibroblasts of the affected tissue, adipocytes and vascular adventitia cells can be sources of CAFs (Puré, Hingorani, 2018; Yin et al., 2019). For the initiation of the CAFs phenotype in some progenitor cells, additional stimulation with cytokines and growth factors, such as transforming growth factor beta (TGF- $\beta$ ), fibroblast growth factor (FGF), and other signaling molecules is required (Table 1) (Bordignon et al., 2019).

Tumor epithelial cells can undergo transformation into CAFs via the epithelial-mesenchymal transition (EMT) (Fig. 1). EMT is a dynamic process of transdifferentiation of epithelial cells into fibroblast-like cells. The EMT plays an important role not only in cancer, but also in embryogenesis and regeneration. In particular, EMT occurs in embryonic stem cells producing mesoderm and neural crest, and in skin cells during wound healing (Kim et al., 2017). Dynamic changes in cell morphology during EMT are caused by changes in the regulatory genes' expression with production of certain proteins. These proteins are considered as EMT markers (see Fig. 1). Among these markers, the most significant are $\mathrm{N}$-cadherin and vimentin, which are responsible for the rear- rangement of the cytoskeleton and the change in the shape of the cell, as well as the change in cell-to-cell and cell-toextracellular matrix (ECM) interactions (Massagué, 2008; Ye, Weinberg, 2015).

In addition to molecular inducers of EMT, the important role of hypoxic conditions has been shown. Hypoxia activates EMT via the binding of the hypoxia-inducible factor (HIF-1) to the promoters of genes responsible for EMT activation. HIF-1 has been shown to increase the expression of the transcription factors genes of the zinc finger motif family such as ZEB1, Snail and SLUG. Overexpression of these factors is associated with the mesenchymal phenotype and a decrease in the abundance of epithelial cell markers - E-cadherin and type 1 tight junction protein (TJP1 or ZO-1) (Nushtaeva et al., 2019; Tam et al., 2020).

Endothelial cells of tumor vessels can undergo an endothelial-mesenchymal transition (EndMT) and acquire the phenotype and functional features of CAFs with the loss of endothelial cells molecular markers, such as the endothelial cell/platelet adhesion molecule (CD31), and the acquisition of markers specific for mesenchymal cells, such as $\alpha$-SMA and fibroblast specific protein 1 (FSP-1) (Zeisberg et al., 2007).

An important component of breast cancer stroma are adipose cells, which can transform into tumor-associated adipocytes, and then into CAFs. Such changes are accompanied by an increase in the expression of molecular markers of mesenchymal cells, including, PPARG (receptors induced by peroxisome activators gamma), RUNX-2 (transcription factor containing the Runt type 2 DNA-binding domain), and SOX9 (transcription factor of the HMG family DNA-binding proteins) (Bochet et al., 2013; Liu et al., 2021).

Using the model of prostate cancer, it was shown that mesenchymal stem cells (MSCs) can differentiate into CAFs after the activation of the chemokine receptor type 6 (CXCR6) by its ligand CXCL16. Moreover, the activation of CXCR6 results in the secretion of stromal factor-1 (CXCL12) involved in EMT (Jung et al., 2013). Weber and colleagues also showed that the extracellular structural protein osteopontin (OPN), which plays a key role in bone formation, activates TGF- $\beta$ gene expression in integrin-dependent MSCs to maintain the phenotype of CAFs in breast cancer. Interestingly, even specialized cells such as Ito cells in the liver, pancreatic stellate cells, and mammary myofibroblasts can acquire the phenotype of CAFs (Weber et al., 2015). These examples illustrate a wide range of cells that, responding to the molecular changes in a tumor, are able to acquire the CAFs' phenotype and, as a consequence, be involved in tumor homeostasis. 
Table 1. The inducers of CAFs phenotype

\begin{tabular}{|c|c|c|}
\hline Inductor & Activation pathway & References \\
\hline TGF- $\beta$ & CLIC4/Arf6 & Calon et al., 2014 \\
\hline FGF & RAS/MAPK, PI3k/AKT & $\begin{array}{l}\text { Bordignon et al., 2019; } \\
\text { Mossahebi-Mohammadi et al., } 2020\end{array}$ \\
\hline PDGF & $\mathrm{PI} 3 \mathrm{k} / \mathrm{AKT}$ & Yoshida, 2020 \\
\hline HSF-1 & TRiC/CCT & $\begin{array}{l}\text { Scherz-Shouval et al., 2014; } \\
\text { Grantham, } 2020\end{array}$ \\
\hline
\end{tabular}

Note. PDGF - platelet derived growth factor; HSF-1 - heat shock factor 1; CLIC4/Arf6 - intracellular chloride channel 4, ADP-ribosylation factor 6; RAS/MAPK - mitogen activated protein kinase; PI3k/AKT - phosphoinositide 3-kinase, alpha serine/threonine protein kinase; TRiC/CCT is a chaperonin containing TCP-1.

Epithelial phenotype

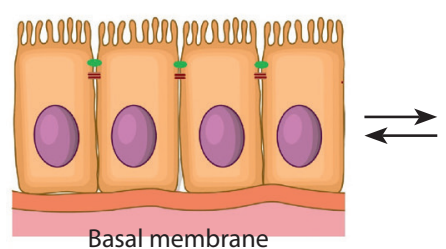

Mesenchymal phenotype

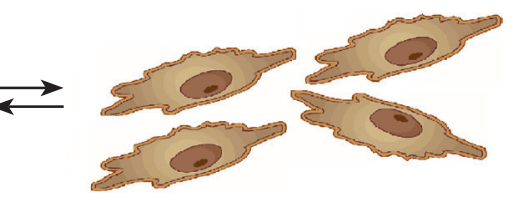

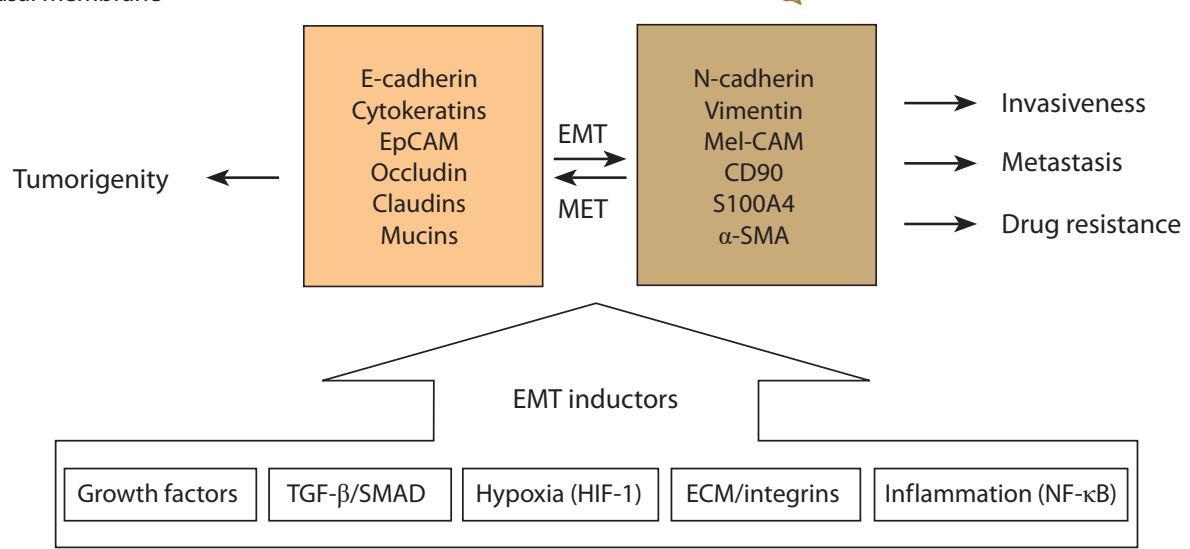

Fig. 1. Cellular and molecular changes during EMF and MET.

EpCAM - epithelial adhesion molecule; Mel-CAM - melanoma adhesion molecule; $\alpha$-SMA - alpha smooth muscle actin; HIF-1 - hypoxia inducible factor 1 .

\section{Markers of cancer-associated fibroblasts}

The involvement of CAFs in carcinogenesis and tumor progression makes them a potential target for the development of novel therapeutic approaches. A potentially clinically significant marker of $\mathrm{CAF}$ is the transmembrane mucin-like protein podoplanin (PDPN) (Table 2); to date, PDPN has been described as a marker of lymphoid capillary progenitor cells and CAFs in lung cancers. Expression of podoplanin was showed in $54(30.5 \%)$ out of 177 CAFs' populations studied in the work of Yurugi et al. Interestingly, all podoplanin-positive CAFs correlated with invasiveness of adenocarcinomas, while a podoplanin-negative phenotype was shown only in noninvasive adenocarcinomas (Yurugi et al., 2017).

Platelet-derived growth factor receptors $\alpha / \beta$ are important markers of CAFs. PDGFR $\alpha / \beta$ belong to the 3 rd class of tyrosine kinases and are activated by interaction with the PDGF ligand. PDGFR regulates the organogenesis of various systems during embryogenesis; however, the significance of the PDGFR $\alpha$ and $-\beta$ receptors activation in tumors is still poorly understood. It has been shown that the expression of the PDGFR $\beta$ receptor is increased in the tumor microenvironment cells, where platelet growth factor activates CAFs and, probably, stimulates cancer progression (Anderberg et al., 2009). PDGFR $\alpha$-positive CAFs have been found in the stroma of melanoma, suggesting that these CAFs originate from resident fibroblasts as a result of their activation (Lynch, Watt, 2018). Serum amyloid A (SAA-1) protein is one of the potential targets of CAFs; its expression and involvement in tumor progression has been shown in CAFs from gastric tumors (Yasukawa et al., 2021).

In the search for specific markers of the tumor stroma cells, among the CAFs of prostate adenocarcinoma, an increased content of the surface protein with a single V-domain of immunoglobulin (CD90), initially found on T cells and neurons, was identified as a specific marker. The high level of CD90 on the cell surface differentiates the tumor-associated stroma and 
Table 2. Potential molecular markers of CAFs

\begin{tabular}{|c|c|c|}
\hline CAFs' markers & Presence in tumors & References \\
\hline$\alpha-S M A$ & Breast cancer & Yang et al., 2021 \\
\hline SAA-1 & Stomach cancer & Yasukawa et al., 2021 \\
\hline Osteopontin & Breast cancer & Weber et al., 2015 \\
\hline Caveolin-1 & Breast cancer: luminal (overexpression), basal (poor expression) & Witkiewicz et al., 2009; Goetz et al., 2011 \\
\hline PDGFR $\alpha / \beta$ & Breast cancer, melanoma & Jansson et al., 2018; Lynch, Watt, 2018 \\
\hline CD90 & Prostate cancer, breast cancer, lung cancer & True et al., 2010; Lobba et al., 2018 \\
\hline Podoplanin & Lung cancer & Yurugi et al., 2017 \\
\hline Metalloprotease & Head-and-neck cancer & Glentis et al., 2017 \\
\hline S100A4 & Breast cancer & Grum-Schwensen et al., 2005 \\
\hline
\end{tabular}

Note. $\alpha$-SMA - alpha-smooth muscle actin; PDGFR $\alpha / \beta$ - platelet-derived growth factor receptors $\alpha / \beta$.

"benign" stroma. Since CD90 expression was shown only in tumor associated fibroblasts, this marker is a potential target for therapy (True et al., 2010).

Certain CAFs proteins can be prognostic markers of tumor invasiveness. One of these markers is a protein from the family of low molecular weight calcium-binding proteins of the S100 - S100A4 family (Fei et al., 2017). S100 family proteins have both intracellular and extracellular activity due to maintaining the calcium balance and $\mathrm{Ca}^{2+}$-dependent processes. S100A4 activates a cascade of reactions associated mainly with the secretion of pro-inflammatory cytokines and the expression of growth factors, extracellular matrix proteins, metalloproteinases, and others. Intracellular activity of S100A4 is of particular interest, and is associated with the enhancement of the invasive capabilities of tumor cells, their escape from apoptosis, and the stem phenotype of the cells (Ambartsumian et al., 2019). During the study of the role of S100A4 in tumor progression, it was shown that suppression of S100A4 decreased tumor growth (Joyce, Pollard, 2009; Grum-Schwensen et al., 2015). The role of stromal cells that secrete S100A4 was shown in the MMTV-PyVmT mouse model with the S100A4 knocked-out gene during orthotopic co-transplantation of CSML100 mouse mammary adenocarcinoma cells and MEF mouse embryonic fibroblasts. MEF cell lines were obtained by spontaneous immortalization of primary embryonic fibroblasts from mouse embryos with the $\mathrm{S} 100 \mathrm{~A}^{+}{ }^{+}$and $\mathrm{S} 100 \mathrm{~A} 4^{-}$phenotypes. Upon co-transplantation of tumor cells and fibroblasts with the S100A4- phenotype in syngeneic mice, no metastases were formed, however, upon transplantation of S100A4 ${ }^{+}$fibroblasts, the metastatic potential of tumor cells returned. S100A4 ${ }^{+}$fibroblasts were characterized by increased mobility and invasiveness compared to S100A4- fibroblasts, as well as the ability to secrete S100A4 into the tumor microenvironment (Grum-Schwensen et al., 2005).

To date, it is clear that the expression of certain CAFs markers does not unambiguously predict the aggressiveness of the tumor. For example, the loss of caveolin-1 in breast cancer CAFs has been shown to be associated with a poor prognosis because the population of these cells stimulates the growth of triple negative (ER-/PR-/HER2-) breast cancer cells (Witkiewicz et al., 2009). In a parallel study, the expression of caveolin-1 in the breast cancer CAFs stimulated the remodeling of the tumor microenvironment, thereby facilitating the invasion of malignant cells and an increased invasiveness level correlated with the metastatic potential of the tumor (Witkiewicz et al., 2009; Goetz et al., 2011). These contradicting results indicate the diverse role of caveolin-1 in histologically different tumors. More studies should be made to determine caveolin-1 as a tumor prognostic marker.

\section{Role of cancer-associated fibroblasts in tumor progression}

CAFs-dependent stimulation of the tumor cells proliferation and their invasion is of particular interest in the study of tumor. This interest is primarily due to the fact that even in the precancerous phenotype of epithelial cells, some resident fibroblasts are already transformed into CAFs (Liotta, Kohn, 2001). Fibroblasts from intestinal tumors and polyps were a good model to confirm the contribution of stromal cells to tumor growth and progression. These fibroblasts were shown to stimulate the proliferation of tumor and polyp cells $(\mathrm{Mu}-$ kaida, Sasaki, 2016).

The interaction of tumor epithelial cells with CAFs was analyzed by comparing the histological picture of various types of gastric cancer. In a study by Orimo and Weinberg, it was demonstrated that in the case of diffuse gastric cancer, CAFs and epithelial cells are more closely spaced, while in the intestinal type, CAFs form a stroma-like matrix, due to which tumor epithelial cells retain their glandular structure (Orimo, Weinberg, 2006).

Using the model of heterogeneous 3D spheroids, consisting of breast cancer epithelial cells and fibroblasts, Dang and colleagues showed that CAFs stimulated the migration of tumor cells of basal breast cancer (ER-/PR-/HER2-). Interestingly, this effect was not observed in the models of luminal breast cancer types (ER+/PR+/HER2+, ER+/PR+/HER2-) (Dang et al., 2011). These data are consistent with clinical observations indicating a higher percentage of metastasis in triplenegative breast cancer compared with other types of breast 

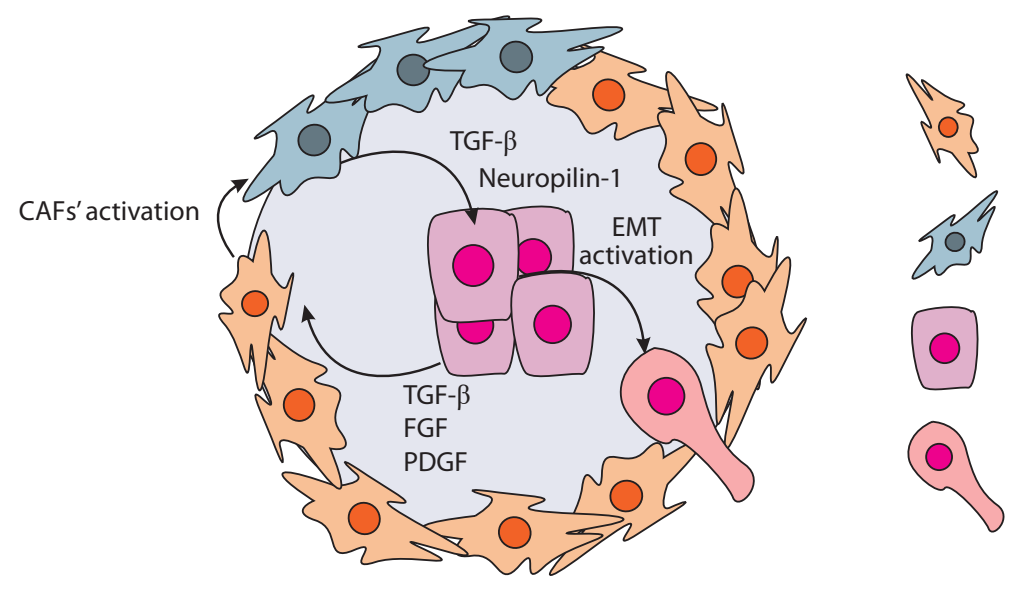

Fibroblast-like cells in stroma

Fibroblast-like cells with the phenotype of cancer-associated fibroblasts (CAFs)

Tumor epithelial cells

Tumor epithelial cells undergoing epithelial-to-mesenchymal transition (EMT)

Fig. 2. The interactions of cancer epithelial cells and stromal elements in the tumor.

TGF- $\beta$ - transforming growth factor- $\beta$; FGF - fibroblast growth factor; PDGF - platelet growth factor.

tumors. However, which factors make cells of basal breast cancer sensitive to CAFs stimulation remain undiscovered (Al-Mahmood et al., 2018).

In order to reach the blood and lymphatic streams, tumor cells should pass through the basement membrane (BM), separating them from connective tissue and vessels. Thus, CAFs are able to synthesize metalloproteinases - endopeptidases capable of destroying proteins of all types of the BM extracellular matrix (Gonzalez-Avila et al., 2019). In 2017, Glentis and colleagues revealed a metalloproteinase-independent CAFssupported overcome of BM by tumor cells. They demonstrated the ability of CAFs to stretch BM with the formation of pores, and through these pores, epithelial tumor cells and CAFs can migrate into the bloodstream and form metastases in distant organs. Interestingly, BM regions with low expression of laminin and type IV collagen exhibited the highest tendency for stretching (Glentis et al., 2017). This alternative CAFsdependent migration pathway explains the ineffectiveness of the metalloproteinase inhibitors application in patients with head and neck tumors.

The paracrine secretion of IL- $1 \alpha$ by CAFs in bladder cancer with further activation of the Wnt pathway in tumor cells is the perfect illustration of the pro-carcinogenic role of CAFs (Yang et al., 2021). Moreover, bladder cancer CAFs secreting IL-8 are able to stimulate the secretion of neuropilin-1, which enhances the proliferation of tumor cells and is one of the potential prognostic markers of malignancy (Chen C. et al., 2020). Interestingly, recent studies have shown that neuropilin-1 may be a co-factor in the induction of EMT (Chen Z. et al., 2020).

Paracrine stimulation of the epithelial-mesenchymal transition in tumor epithelial cells by CAFs is an important factor contributing to tumor progression. The central mechanism of EMT in the tumor is the TGF- $\beta /$ Smad pathway activation, induced by TGF- $\beta$ from stromal fibroblasts (Fig. 2) (Yu et al., 2014). The Smad factor is a transcription factor that controls the expression of EMT genes. Vered and colleagues showed that cells with EMT markers are found in primary foci of squamous cell carcinoma of the tongue as well as in regional lymph nodes metastases. This confirms the importance of
CAFs in the induction of metastasis and in the formation of a secondary tumor node (Vered et al., 2010).

The central mechanism of the EMT activation in ovarian cancer is the induction of the CXCR4/Wnt/ $\beta$-catenin pathway in tumor epithelial cells. CAFs secreting stromal growth factor-1 (SDF-1 or CXCL12) have been shown to be the major players in this process. Moreover, SDF-1 is also interlinked with the resistance of tumor cells to chemotherapeutic agents such as cisplatin (Zhang et al., 2020).

In 2020, Franzè and colleagues demonstrated the activation of CAFs phenotype in normal fibroblasts from rectal polyps co-cultured with CAFs. They showed that CAFs derived from colorectal tumors can secrete IL-34, which in normal fibroblasts activates the expression of CAFs markers such as $\alpha$-SMA, vimentin, and fibroblast activating protein (FAP) (Franzè et al., 2020).

Even though most of the described functions of CAFs are associated with the stimulation of tumor progression, some authors also describe CAFs as tumor-suppressing players. For example, the subpopulation of CAFs expressing the melanoma adhesion molecule (CD146) in breast tumors correlated with a retarded cell proliferation in estrogen-dependent types of breast cancer (Brechbuhl et al., 2017). Since CAFs secrete cytokines involved in the recruitment and maturation of macrophages, T-lymphocytes and natural killer cells (IL-10, TGF- $\beta$, TNF, IFN- $\gamma$ and IL-6), they increase the availability of the tumor to immune cells and promote antitumor immune response (Marlow et al., 2008). In the study of oral cancer, it was also shown that CAFs can suppress the proliferation of tumor cells. In particular, the population of CAFs secreting Bone Morphogenetic Protein 4 (BMP4) and expressing $\alpha$-SMA inhibited the proliferation of cancer stem cells (CSC) (Patel et al., 2018). Using the mice model with a predisposition for the development of pancreatic cancer, Rhim and colleagues exhibited the role of CAFs in cancer progression. They excluded the $\alpha$-SMA-positive population of CAFs or CAFs with inhibited Hedgehog signaling pathway. These modifications suppress the growth of pancreatic ductal adenocarcinoma. Histological analysis of tumors revealed abnormalities in the vessel's formation (Rhim et al., 2014). 
These examples demonstrate the tumor-suppressing function of CAFs only in high differentiated cancers with no similarity in undifferentiated ones. It can be assumed that apart from origin and tissue of the affected organ, the function of CAFs is determined by the differentiation stage of cancer cells (Bu et al., 2019).

\section{Isolation of CAFs for research purposes}

Cell cultures obtained from patients' tumors after surgery are most often used to study the properties of CAFs. It is necessary to establish new CAFs cell cultures, since in vitro CAFs tend to age rapidly, and the possibilities of their use are limited by early passages (Taddei et al., 2014). Moreover, in commercially available cell collections American Type Culture Collection (ATCC), European Collection of Authenticated Cell Cultures (ECACC), Russian collection of cell cultures, etc. cell lines with the CAFs phenotype are limited. For instance, in ATCC, only one CAFs cell line is available. This cell culture originates from the prostate adenocarcinoma and is modified by the introduction of the telomerase transgene under the control of the constitutive promoter of the polyoma virus SV40 hTERT PF179T CAF. This modification of fibroblasts is aimed at maintaining the proliferative properties of CAFs (Madar et al., 2009).

To obtain cell cultures from tumor tissue, mechanical disaggregation, enzymatic dissociation, chelation and their combination are used. Trypsin and type IV collagenase are most often used to destroy the stroma of tumor tissue. The choice of what technique to use should consider the histological origin of the tissue of interest. When tissue disaggregated, CAFs can represent a small population of cells and obtaining a monoculture requires an additional stage of their separation from the total cell mass. In order to isolate a particular population of CAFs, magnetic separation, or FACS of cells with immunostaining of specific CAFs markers such as FAP or $\alpha$-SMA are used (Sharon et al., 2013; Huang et al., 2017; Sha et al., 2018). The main difficulty in isolating CAFs lies in adapting protocols for vital staining of intracellular markers such as $\alpha$-SMA, FAP, and vimentin. Therefore, it is highly desirable to include surface markers such as CD90 in the analysis.

\section{Conclusion}

Clear understanding the tumor microenvironment role is crucial for the development of new approaches in cancer diagnostics and treatment. The multifaceted influence of CAFs on tumor progression makes them an important object for the study of carcinogenesis and the development of new antitumor agents. The use of drugs targeted to the components of the tumor microenvironment has not demonstrated efficacy for anti-metalloproteinase compounds and angiogenesis inhibitors as well as T-cell immunity checkpoints inhibitors in some types of cancer (Wang-Gillam, 2019). The heterogeneity of the molecular phenotypes of CAFs can be an important factor in the failure of CAF-targeted cancer treatment. The scientific community should develop more detailed classifications of various subtypes of CAFs considering their involvement in tumor progression.

Thus, a detailed classification of CAFs and a study of the functions of each phenotypic subgroup may provide im- portant knowledge for the development of new methods for the CAF-related treatment and diagnosis of oncological diseases.

\section{References}

Alkasalias T., Moyano-Galceran L., Arsenian-Henriksson M., Lehti K. Fibroblasts in the tumor microenvironment: shield or spear? Int. J. Mol. Sci. 2018;19(5):1532. DOI 10.3390/ijms19051532.

Al-Mahmood S., Sapiezynski J., Garbuzenko O.B., Minko T. Metastatic and triple-negative breast cancer: challenges and treatment options. Drug Deliv. Transl. Res. 2018;8(5):1483-1507. DOI 10.1007/ s13346-018-0551-3.

Ambartsumian N., Klingelhöfer J., Grigorian M. The multifaceted S100A4 protein in cancer and inflammation. In: Heizmann C. (Ed.). Calcium-Binding Proteins of the EF-Hand Superfamily: From Basics to Medical Applications. (Ser. Methods in Molecular Biology). New York: Humana Press, 2019;1929:339-365. DOI 10.1007/9781-4939-9030-6 22.

Anderberg C., Li H., Fredriksson L., Andrae J., Betsholtz C., Li X., Eriksson U., Pietras K. Paracrine signaling by platelet-derived growth factor-CC promotes tumor growth by recruitment of cancer-associated fibroblasts. Cancer Res. 2009;69(1):369-378. DOI 10.1158/0008-5472.CAN-08-2724.

Bochet L., Lehuede C., Dauvillier S., Wang Y.Y., Dirat B., Laurent V., Dray C., Guiet R., Maridonneau-Parini I., Le Gonidec S., Couderc B., Escourrou G., Valet P., Muller C. Adipocyte-derived fibroblasts promote tumor progression and contribute to the desmoplastic reaction in breast cancer. Cancer Res. 2013;73(18):5657-5668. DOI 10.1158/0008-5472.CAN-13-0530.

Bordignon P., Bottoni G., Xu X., Popescu A.S., Truan Z., Guenova E., Kofler L., Jafari P., Ostano P., Röcken M., Neel V., Dotto G.P. Dualism of FGF and TGF- $\beta$ signaling in heterogeneous cancer-associated fibroblast activation with ETV1 as a critical determinant. Cell Rep. 2019;28(9):2358-2372.e6. DOI 10.1016/j.celrep.2019.07.092.

Brechbuhl H.M., Finlay-Schultz J., Yamamoto T.M., Gillen A.E., Cittelly D.M., Tan A.-C., Sams S.B., Pillai M.M., Elias A.D., Robinson W.A., Sartorius C.A., Kabos P. Fibroblast subtypes regulate responsiveness of luminal breast cancer to estrogen. Clin. Cancer Res. 2017;23(7):1710-1721. DOI 10.1158/1078-0432.CCR-15-2851.

Bu L., Baba H., Yoshida N., Miyake K., Yasuda T., Uchihara T., Tan P., Ishimoto T. Biological heterogeneity and versatility of cancer-associated fibroblasts in the tumor microenvironment. Oncogene. 2019; 38(25):4887-4901. DOI 10.1038/s41388-019-0765-y.

Calon A., Tauriello D.V.F., Batlle E. TGF-beta in CAF-mediated tumor growth and metastasis. Semin. Cancer Biol. 2014;25:15-22. DOI 10.1016/j.semcancer.2013.12.008.

Chen C., Zhang R., Ma L., Li Q., Zhao Y., Zhang G., Zhang D., Li W., Cao S., Wang L., Geng Z. Neuropilin-1 is up-regulated by cancerassociated fibroblast-secreted IL-8 and associated with cell proliferation of gallbladder cancer. J. Cell. Mol. Med. 2020;24(21):1260812618. DOI $10.1111 / \mathrm{jcmm} .15825$.

Chen Z., Gao H., Dong Z., Shen Y., Wang Z., Wei W., Yi J., Wang R., $\mathrm{Wu}$ N., Jin $\mathrm{S}$. NRP1 regulates radiation-induced EMT via TGF- $\beta$ / Smad signaling in lung adenocarcinoma cells. Int. J. Radiat. Biol. 2020;96(10):1281-1295. DOI 10.1080/09553002.2020.1793015.

Dang T.T., Prechtl A.M., Pearson G.W. Breast cancer subtype-specific interactions with the microenvironment dictate mechanisms of invasion. Cancer Res. 2011;71(21):6857-6866. DOI 10.1158/00085472.CAN-11-1818.

Fei F., Qu J., Zhang M., Li Y., Zhang S. S100A4 in cancer progression and metastasis: a systematic review. Oncotarget. 2017;8(42):7321973239. DOI 10.18632/oncotarget.18016.

Franzè E., Di Grazia A., Sica G.S., Biancone L., Laudisi F., Monteleone G. Interleukin-34 enhances the tumor promoting function of colorectal cancer-associated fibroblasts. Cancers. 2020;12(12):3537. DOI 10.3390/cancers12123537. 
Glentis A., Oertle P., Mariani P., Chikina A., El Marjou F., Attieh Y., Zaccarini F., Lae M., Loew D., Dingli F., Sirven P., Schoumacher M., Gurchenkov B.G., Plodinec M., Vignjevic D.M. Cancer-associated fibroblasts induce metalloprotease-independent cancer cell invasion of the basement membrane. Nat. Commun. 2017;8(1):924. DOI 10.1038/s41467-017-00985-8.

Goetz J.G., Minguet S., Navarro-Lérida I., Lazcano J.J., Samaniego R., Calvo E., Tello M., Osteso-Ibáñez T., Pellinen T., Echarri A., Cerezo A., Klein-Szanto A.J.P., Garcia R., Keely P.J., Sánchez-Mateos P., Cukierman E., Del Pozo M.A. Biomechanical remodeling of the microenvironment by stromal caveolin-1 favors tumor invasion and metastasis. Cell. 2011;146(1):148-163. DOI 10.1016/j.cell.2011.05. 040.

Gonzalez-Avila G., Sommer B., Mendoza-Posada D.A., Ramos C., Garcia-Hernandez A.A., Falfan-Valencia R. Matrix metalloproteinases participation in the metastatic process and their diagnostic and therapeutic applications in cancer. Crit. Rev. Oncol. Hematol. 2019; 137:57-83. DOI 10.1016/j.critrevonc.2019.02.010.

Grantham J. The molecular chaperone CCT/TRiC: an essential component of proteostasis and a potential modulator of protein aggregation. Front. Genet. 2020;11:172. DOI 10.3389/fgene.2020.00172.

Grum-Schwensen B., Klingelhöfer J., Beck M., Bonefeld C.M., Hamerlik P., Guldberg P., Grigorian M., Lukanidin E., Ambartsumian N. S100A4-neutralizing antibody suppresses spontaneous tumor progression, pre-metastatic niche formation and alters T-cell polarization balance. BMC Cancer. 2015;15(1):44. DOI 10.1186/ s12885-015-1034-2.

Grum-Schwensen B., Klingelhofer J., Berg C.H., El-Naaman C., Grigorian M., Lukanidin E., Ambartsumian N. Suppression of tumor development and metastasis formation in mice lacking the $\mathrm{S} 100 \mathrm{~A} 4(\mathrm{mts} 1)$ gene. Cancer Res. 2005;65(9):3772-3780. DOI 10.1158/0008-5472. CAN-04-4510.

Hosein A.N., Wu M., Arcand S.L., Lavallée S., Hébert J., Tonin P.N., Basik M. Breast carcinoma-associated fibroblasts rarely contain p53 mutations or chromosomal aberrations. Cancer Res. 2010; 70(14):5770-5777. DOI 10.1158/0008-5472.CAN-10-0673.

Huang Yingying, Zhou S., Huang Yong, Zheng D., Mao Q., He J., Wang Y., Xue D., Lu X., Yang N., Zhao Y. Isolation of fibroblast-activation protein-specific cancer-associated fibroblasts. BioMed Res. Int. 2017;2017:4825108. DOI 10.1155/2017/4825108.

Jansson S., Aaltonen K., Bendahl P.-O., Falck A.-K., Karlsson M., Pietras K., Rydén L. The PDGF pathway in breast cancer is linked to tumour aggressiveness, triple-negative subtype and early recurrence. Breast Cancer Res. Treat. 2018;169(2):231-241. DOI 10.1007/ s10549-018-4664-7.

Joyce J.A., Pollard J.W. Microenvironmental regulation of metastasis. Nat. Rev. Cancer. 2009;9(4):239-252. DOI 10.1038/nrc2618.

Jung Y., Kim J.K., Shiozawa Y., Wang Jingcheng, Mishra A., Joseph J., Berry J.E., McGee S., Lee E., Sun H., Wang Jianhua, Jin T., Zhang H., Dai J., Krebsbach P.H., Keller E.T., Pienta K.J., Taichman R.S. Recruitment of mesenchymal stem cells into prostate tumours promotes metastasis. Nat. Commun. 2013;4(1):1795. DOI $10.1038 /$ ncomms 2766 .

Kim D., Xing T., Yang Z., Dudek R., Lu Q., Chen Y.-H. Epithelial mesenchymal transition in embryonic development, tissue repair and cancer: a comprehensive overview. J. Clin. Med. 2017;7(1):1. DOI $10.3390 / \mathrm{jcm} 7010001$

Knops A.M., South A., Rodeck U., Martinez-Outschoorn U., Harshyne L.A., Johnson J., Luginbuhl A.J., Curry J.M. Cancer-associated fibroblast density, prognostic characteristics, and recurrence in head and neck squamous cell carcinoma: a meta-analysis. Front. Oncol. 2020;10:565306. DOI 10.3389/fonc.2020.565306.

Liotta L.A., Kohn E.C. The microenvironment of the tumour-host interface. Nature. 2001;411(6835):375-379. DOI 10.1038/35077241.

Liu B., Pan S., Liu J., Kong C. Cancer-associated fibroblasts and the related Runt-related transcription factor 2 (RUNX2) promote bladder cancer progression. Gene. 2021;775:145451. DOI 10.1016/j.gene. 2021.145451
Lobba A.R.M., Carreira A.C.O., Cerqueira O.L.D., Fujita A., DeOcesano-Pereira C., Osorio C.A.B., Soares F.A., Rameshwar P., Sogayar M.C. High CD90 (THY-1) expression positively correlates with cell transformation and worse prognosis in basal-like breast cancer tumors. PLoS One. 2018;13(6):e0199254. DOI 10.1371/journal. pone. 0199254

Lynch M.D., Watt F.M. Fibroblast heterogeneity: implications for human disease. J. Clin. Investig. 2018;128(1):26-35. DOI 10.1172/ JCI93555.

Madar S., Brosh R., Buganim Y., Ezra O., Goldstein I., Solomon H., Kogan I., Goldfinger N., Klocker H., Rotter V. Modulated expression of WFDC1 during carcinogenesis and cellular senescence. Carcinogenesis. 2009;30(1):20-27. DOI 10.1093/carcin/bgn232.

Marlow R., Strickland P., Lee J.S., Wu X., Pebenito M., Binnewies M., Le E.K., Moran A., Macias H., Cardiff R.D., Sukumar S., Hinck L. SLITs suppress tumor growth in vivo by silencing Sdf1/Cxcr4 within breast epithelium. Cancer Res. 2008;68(19):7819-7827. DOI 10.1158/0008-5472.CAN-08-1357.

Massagué J. TGF $\beta$ in cancer. Cell. 2008;134(2):215-230. DOI 10.1016/ j.cell.2008.07.001.

Mossahebi-Mohammadi M., Quan M., Zhang J.-S., Li X. FGF signaling pathway: a key regulator of stem cell pluripotency. Front. Cell Dev. Biol. 2020;8:79. DOI 10.3389/fcell.2020.00079.

Mukaida N., Sasaki S. Fibroblasts, an inconspicuous but essential player in colon cancer development and progression. World J. Gastroenterol. 2016;22(23):5301. DOI 10.3748/wjg.v22.i23.5301.

Nushtaeva A.A., Karpushina A.A., Ermakov M.S., Gulyaeva L.F., Gerasimov A.V., Sidorov S.V., Gayner T.A., Yunusova A.Y., Tkachenko A.V., Richter V.A., Koval O.A. Establishment of primary human breast cancer cell lines using "pulsed hypoxia" method and development of metastatic tumor model in immunodeficient mice. Cancer Cell Int. 2019;19(1):46. DOI 10.1186/s12935-019-0766-5.

Nushtaeva A.A., Stepanov G.A., Semenov D.V., Juravlev E.S., Balahonova E.A., Gerasimov A.V., Sidorov S.V., Savelyev E.I., Kuligina E.V., Richter V.A., Koval O.A. Characterization of primary normal and malignant breast cancer cell and their response to chemotherapy and immunostimulatory agents. BMC Cancer. 2018;18(1):728. DOI 10.1186/s12885-018-4635-8.

Orimo A., Weinberg R.A. Stromal fibroblasts in cancer: a novel tumor-promoting cell type. Cell Cycle. 2006;5(15):1597-1601. DOI 10.4161/cc.5.15.3112.

Patel A.K., Vipparthi K., Thatikonda V., Arun I., Bhattacharjee S., Sharan R., Arun P., Singh S. A subtype of cancer-associated fibroblasts with lower expression of alpha-smooth muscle actin suppresses stemness through BMP4 in oral carcinoma. Oncogenesis. 2018; 7(10):78. DOI 10.1038/s41389-018-0087-x.

Puré E., Hingorani S.R. Mesenchymal cell plasticity and perfidy in epithelial malignancy. Trends Cancer. 2018;4(4):273-277. DOI 10.1016/j.trecan.2018.02.007.

Rhim A.D., Oberstein P.E., Thomas D.H., Mirek E.T., Palermo C.F., Sastra S.A., Dekleva E.N., Saunders T., Becerra C.P., Tattersall I.W., Westphalen C.B., Kitajewski J., Fernandez-Barrena M.G., Fernandez-Zapico M.E., Iacobuzio-Donahue C., Olive K.P., Stanger B.Z. Stromal elements act to restrain, rather than support, pancreatic ductal adenocarcinoma. Cancer Cell. 2014;25(6):735-747. DOI 10.1016/j.ccr.2014.04.021.

Rønnov-Jessen L., Petersen O.W., Koteliansky V.E., Bissell M.J. The origin of the myofibroblasts in breast cancer. Recapitulation of tumor environment in culture unravels diversity and implicates converted fibroblasts and recruited smooth muscle cells. J. Clin. Invest. 1995;95(2):859-873. DOI 10.1172/JCI117736.

Scherz-Shouval R., Santagata S., Mendillo M.L., Sholl L.M., BenAharon I., Beck A.H., Dias-Santagata D., Koeva M., Stemmer S.M., Whitesell L., Lindquist S. The reprogramming of tumor stroma by HSF1 is a potent enabler of malignancy. Cell. 2014;158(3):564-578. DOI 10.1016/j.cell.2014.05.045.

Sha M., Jeong S., Qiu B., Tong Y., Xia L., Xu N., Zhang J., Xia Q. Isolation of cancer-associated fibroblasts and its promotion to the 
progression of intrahepatic cholangiocarcinoma. Cancer Med. 2018; 7(9):4665-4677. DOI 10.1002/cam4.1704.

Sharon Y., Alon L., Glanz S., Servais C., Erez N. Isolation of normal and cancer-associated fibroblasts from fresh tissues by Fluorescence Activated Cell Sorting (FACS). J. Vis. Exp. 2013;71:4425. DOI $10.3791 / 4425$.

Taddei M.L., Cavallini L., Comito G., Giannoni E., Folini M., Marini A., Gandellini P., Morandi A., Pintus G., Raspollini M.R., Zaffaroni N., Chiarugi P. Senescent stroma promotes prostate cancer progression: the role of miR-210. Mol. Oncol. 2014;8(8):1729-1746. DOI 10.1016/j.molonc.2014.07.009.

Tam S.Y., Wu V.W.C., Law H.K.W. Hypoxia-induced epithelial-mesenchymal transition in cancers: HIF-1 $\alpha$ and beyond. Front. Oncol. 2020;10:468. DOI 10.3389/fonc.2020.00486.

Tripathi M., Billet S., Bhowmick N.A. Understanding the role of stromal fibroblasts in cancer progression. Cell Adh. Migr. 2012;6(3): 231-235. DOI 10.4161/cam.20419.

True L.D., Zhang H., Ye M., Huang C.-Y., Nelson P.S., von Haller P.D., Tjoelker L.W., Kim J.-S., Qian W.-J., Smith R.D., Ellis W.J., Liebeskind E.S., Liu A.Y. CD90/THY1 is overexpressed in prostate cancerassociated fibroblasts and could serve as a cancer biomarker. Mod. Pathol. 2010;23(10):1346-1356. DOI 10.1038/modpathol.2010.122.

Vered M., Dayan D., Yahalom R., Dobriyan A., Barshack I., Bello I.O., Kantola S., Salo T. Cancer-associated fibroblasts and epithelial-mesenchymal transition in metastatic oral tongue squamous cell carcinoma. Int. J. Cancer. 2010;127(6):1356-1362. DOI 10.1002/ijc.25358.

Wang M., Zhao J., Zhang L., Wei F., Lian Y., Wu Y., Gong Z., Zhang S., Zhou J., Cao K., Li X., Xiong W., Li G., Zeng Z., Guo C. Role of tumor microenvironment in tumorigenesis. J. Cancer. 2017;8(5): 761-773. DOI 10.7150/jca.17648.

Wang-Gillam A. Targeting stroma: a tale of caution. J. Clin. Oncol. 2019;37(13):1041-1043. DOI 10.1200/JCO.19.00056.

Weber C.E., Kothari A.N., Wai P.Y., Li N.Y., Driver J., Zapf M.A.C., Franzen C.A., Gupta G.N., Osipo C., Zlobin A., Syn W.K., Zhang J., Kuo P.C., Mi Z. Osteopontin mediates an MZF1-TGF- $\beta 1$-dependent transformation of mesenchymal stem cells into cancer-associated fibroblasts in breast cancer. Oncogene. 2015;34(37):4821-4833. DOI 10.1038/onc.2014.410.

Witkiewicz A.K., Dasgupta A., Sotgia F., Mercier I., Pestell R.G., Sabel M., Kleer C.G., Brody J.R., Lisanti M.P. An absence of stromal caveolin-1 expression predicts early tumor recurrence and poor clinical outcome in human breast cancers. Am. J. Pathol. 2009;174(6): 2023-2034. DOI 10.2353/ajpath.2009.080873.

Yang F., Guo Z., He C., Qing L., Wang H., Wu J., Lu X. Cancer-associated fibroblasts promote cell proliferation and invasion via paracrine Wnt/IL1 $\beta$ signaling pathway in human bladder cancer. Neoplasma. 2021;68(1):79-86. DOI 10.4149/neo_2020_200202N101.

Yasukawa Y., Hattori N., Iida N., Takeshima H., Maeda M., Kiyono T., Sekine S., Seto Y., Ushijima T. SAA1 is upregulated in gastric cancer-associated fibroblasts possibly by its enhancer activation. Carcinogenesis. 2021;42(2):180-189. DOI 10.1093/carcin/bgaa131.

Ye X., Weinberg R.A. Epithelial-mesenchymal plasticity: a central regulator of cancer progression. Trends Cell Biol. 2015;25(11):675686. DOI 10.1016/j.tcb.2015.07.012.

Yin Z., Dong C., Jiang K., Xu Z., Li R., Guo K., Shao S., Wang L. Heterogeneity of cancer-associated fibroblasts and roles in the progression, prognosis, and therapy of hepatocellular carcinoma. J. Hematol. Oncol. 2019;12(1):101. DOI 10.1186/s13045-019-0782-x.

Yoshida G.J. Regulation of heterogeneous cancer-associated fibroblasts: the molecular pathology of activated signaling pathways. J. Exp. Clin. Cancer Res. 2020;39(1):112. DOI 10.1186/s13046020-01611-0

Yu Y., Xiao C.-H., Tan L.-D., Wang Q.-S., Li X.-Q., Feng Y.-M. Cancer-associated fibroblasts induce epithelial-mesenchymal transition of breast cancer cells through paracrine TGF- $\beta$ signalling. $B r . J$. Cancer. 2014;110(3):724-732. DOI 10.1038/bjc.2013.768.

Yurugi Y., Wakahara M., Matsuoka Y., Sakabe T., Kubouchi Y., Haruki T., Nosaka K., Miwa K., Araki K., Taniguchi Y., Shiomi T., Nakamura H., Umekita Y. Podoplanin expression in cancer-associated fibroblasts predicts poor prognosis in patients with squamous cell carcinoma of the lung. Anticancer. Res. 2017;37(1):207-214. DOI 10.21873/anticanres.11308.

Zeisberg E.M., Potenta S., Xie L., Zeisberg M., Kalluri R. Discovery of endothelial to mesenchymal transition as a source for carcinomaassociated fibroblasts. Cancer Res. 2007;67(21):10123-10128. DOI 10.1158/0008-5472.CAN-07-3127.

Zhang F., Cui J., Gao H., Yu H., Gao F., Chen J., Chen L. Cancerassociated fibroblasts induce epithelial-mesenchymal transition and cisplatin resistance in ovarian cancer via CXCL12/CXCR4 axis. Future Oncol. 2020;16(32):2619-2633. DOI 10.2217/fon-2020-0095.

\section{ORCID ID}

M.S. Ermakov orcid.org/0000-0001-7107-4187

A.A. Nushtaeva orcid.org/0000-0001-9367-807X

O.A. Koval orcid.org/0000-0001-7788-2249

Acknowledgements. This research was funded by the Russian Science Foundation, grant number 20-74-10039 and Russian State funded budget project of ICBFM SB RAS No. AAAA-A17-117020210023-1.

Conflict of interest. The authors declare no conflict of interest.

Received July 19, 2021. Revised November 10, 2021. Accepted November 12, 2021. 